\title{
ANALISIS PERHITUNGAN, PENYETORAN DAN PELAPORAN PAJAK PENGHASILAN PASAL 21 PADA PT INTRACO PENTA PRIMA SERVIS (IPPS)
}

\author{
Aditya Rachman Padja \\ Jantje J. Tinangon \\ Victorina Z. Tirayoh \\ Fakultas Ekonomi dan Bisnis, Jurusan Akuntansi \\ Universitas Sam Ratulangi Manado \\ email : aditpadja@yahoo.com
}

\begin{abstract}
ABSTRAK
Pajak Penghasilan Pasal 21 adalah Pajak yang dipotong oleh pihak lain atas penghasilan berupa gaji, upah, honorarium, tunjangan, dan pembayaran lain dengan nama dan dalam bentuk apapun sehubungan dengan pekerjaan, jasa, atau kegiatan yang dilakukan oleh Wajib Pajak orang pribadi dalam negeri. Atas dasar tersebut, Kantor atau Instansi Pemerintahan yang menggaji pegawai tetapnya wajib memotong, menyetor, dan melapor Pajak Penghasilan Pasal 21 atas penghasilan yang diterima pegawainya setiap bulan melalui Surat Pemberitahuan, SPT Masa. Penelitian ini dilaksanakan di PT Intraco Penta Prima Servis (IPPS), Tujuan dari Penelitian ini dilakukan yaitu untuk mengetahui apakah Perhitungan, Penyetoran, dan Pelaporan Pajak Penghasilan Pasal 21 Pada PT Intraco Penta Prima Servis (IPPS) apakah sudah sesuai dengan Undang-Undang No.36 Tahun 2008 Tentang Pajak Penghasilan. Penelitian ini menggunakan metode penelitian deskriptif, dan Teknik Pengumpulan Data yang digunakan adalah teknik Wawancara dan Dokumentasi. Hasil dari penelitian ini menunjukkan bahwa penerapan Perhitungan, Penyetoran, dan Pelaporan Pajak Penghasilan Pasal 21 yang dilakukan oleh PT Intraco Penta Prima Servis(IPPS) telah sesuai dengan Undang-Undang No.36 Tahun 2008 Tentang Pajak Penghasilan, dan juga diharapkan agar pihak fiskus harus lebih banyak memberikan sosialisasi mengenai Pajak Penghasilan Pasal 21 kepada Wajib Pajak khususnya yang bertindak sebagai pemotong atau pemungut pajak sehingga tidak terjadi lagi kesalahan-kesalahan dalam perhitungan.
\end{abstract}

Kata Kunci: perhitungan, penyetoran dan pelaporan PPh pasal 21

\begin{abstract}
Income Tax Article 21 is Tax withheld by others on income in the form of salaries, wages, honoraria, allowances, and other payments by the name and in any form in connection with employment, services, or activities undertaken by individual taxpayers in the country. On this basis, the Office of Government Agencies that hire or permanent employee is obliged to withhold, deposit, and report of Income Tax Article 21 on income received by employees every month through the Tax return period. This research was conducted in PT Intraco Penta Prima Servis (IPPS), The purpose of this research was conducted is to determine whether the calculation, remittance, and Article 21 of the Income Tax Reporting at PT Intraco Penta Prima Services (IPPS) if it is in accordance with Law No.36 Year 2008 on Income Tax. This study used descriptive research methods, and data collection technique used is the technique of interview, and documentation. The results of this study indicate that the application of the calculation, remittance, and Article 21 of the Income Tax Reporting by PT Intraco Penta Prima Services (IPPS) in accordance with Act 36 of 2008 on Income Tax, and is also expected that the tax authorities should provide more socialization of Income Tax Article 21 taxpayers, especially acting as a cutter or a tax collector that does not happen anymore mistakes in calculations.
\end{abstract}

Keywords : calculation, deposit and reporting of income tax article 21 


\section{PENDAHULUAN}

\section{Latar Belakang}

Pajak merupakan aspek yang penting dalam proses pembangunan suatu Negara khususnya di Indonesia, karena pembangunan bertujuan untuk mewujudkan serta meningkatkan kesejahteraan suatu bangsa, Dalam hal ini peranan Pajak sebagai sumber pembiayaan dalam pembangunan disuatu Negara. Disimpulkan bahwa tanpa penerimaan Pajak yang optimal maka proses pembangunan tidak akan berjalan dengan baik.Pajak merupakan iuran wajib yang diberlakukan pada setiap pajak atas objek pajak yang dimilikinya dan hasilnya diserahkan kepada pemerintah. Jenis pajak yang diberlakukan di Indonesia diantaranya adalah Pajak Penghasilan, Pajak Pertambahan nilai, Pajak Bumi dan Bangunan, Pajak Hiburan, Pajak Hadiah dan lain-lain.

Pajak Penghasilan merupakan pajak yang dipungut pada objek pajak atas Penghasilannya, Pajak Penghasilan akan selalu dikenakan terhadap orang atau badan usaha yang memperoleh penghasilan di Indonesia maupun dari luar Indonesia. Pajak yang berlaku bagi pegawai atau karyawan adalah Pajak Penghasilan Pasal 21. Setiap orang yang bekerja tentu saja akan mendapatkan penghasilan dari pekerjaan tersebut, demikian juga dengan karyawan yang bekerja pada sebuah perusahaan, tentunya akan mendapatkan penghasilan yang biasanya disebut gaji, atas penghasilan yang diterimanya, pemerintah akan menarik pajak dari penghasilan tersebut.

Sistem pemungutan pajak di Indonesia adalah self assessment yaitu suatu sistem pemungutan pajak yang memberi wewenang penuh kepada wajib pajak untuk menghitung, membayar dan melaporkan sendiri besarnya utang pajak. berdasarkan self assessment system, masyarakatlah yang paling menentukan dalam melaksanakan kewajiban perpajakan, mulai dari mendaftarkan diri sebagai Wajib Pajak, menghitung besarnya pajak terutang, membayar pajaknya sendiri ke bank atau kekantor pos, dan melaporkannya ke Kantor Pelayanan Pajak (KPP). Pemerintah berharap dengan self assessment system, pelaksanaan pemungutan pajak penghasilan dapat berjalan dengan lebih mudah dan lancar, Pajak yang berlaku bagi karyawan adalah Pajak Penghasilan Pasal 21, dalam hal perhitungan Pajak Penghasilan Pasal 21 karyawan, biasanya akan dilakukan oleh perusahaan tempat karyawan tersebut bekerja.

Prinsipnya PT Intraco Penta Prima Servis, (IPPS), melakukan Perhitungan, Penyetoran, dan Pelaporan Pajak, tetapi tidak jarang ditemui kekeliruan didalam pelaporan Pajak Penghasilan Pasal 21 yang akan disetor, dimana perubahan terhadap status wajib pajak orang pribadi (karyawan perusahaan) tidak dapat diakui di dalam Undang-Undang Perpajakan seperti perubahan status karyawan atas tanggungannya yang terjadi diluar tahun pajak yang bersangkutan. Mungkin ada lagi kendala atau kekeliruan lainnya, termasuk didalam angka-angka perhitungan Pajak Penghasilan Pasal 21.

\section{Tujuan Penelitian}

Tujuan yang hendak dicapai melalui penelitian ini adalah untuk mengetahui apakah Perhitungan, Penyetoran dan Pelaporan Pajak Penghasilan Pasal 21 pada PT Intraco Penta Prima Servis (IPPS) telah sesuai dengan Undang-Undang Perpajakan No.36 Tahun 2008 tentang Pajak Penghasilan. 


\section{TINJAUAN PUSTAKA}

\section{Pajak Penghasilan Pasal 21}

Pajak Penghasilan Pasal 21 adalah Pajak atas penghasilan berupa gaji, upah, honorarium, tunjangan dan pembayaran lainnya yang diterima atau diperoleh wajib pajak orang pribadi dalam negeri sehubungan dengan pekerjaan atau jabatan, jasa, dan kegiatan yang dilakukan oleh orang pribadi. subjek pajak dalam negri, sebagaimana dimaksud dalam pasal 21 Undang-Undang Pajak Penghasilan.

\section{Pemotong Pajak Penghasilan Pasal 21} adalah:

Mardiasmo (2009:164) menyatakan bahwa yang termasuk pemotong Pajak Penghasilan Pasal 21

1. Pemberi kerja, yang terdiri dari orang pribadi dan badan, baik merupakan pusat maupun cabang, perwakilan atau unit yang membayar gaji, upah, honorarium, tunjangan, dan pembayaran lain dengan nama dan dalam bentuk apapun, sebagai imbalan sehubungan dengan pekerjaaan atau jasa yang dilakukan oleh pegawai atau bukan pegawai;

2. Bendahara atau pemegang kas pemerintah, termasuk bendahara atau pemegang kas pada Pemerintah Pusat termasuk institusi TNI/POLRI, Pemerintah Daerah, instansi atau lembaga pemerintah lembaga pemerintah, lembaga-lembaga negara lainnya, dan Kedutaan Besar Republik Indonesia di luar negeri, yang membayarkan gaji, upah, honorarium, tunjangan, dan pembayaran lain dengan nama dan dalam bentuk apa pun sehubungan dengan pekerjaan atau jabatan, jasa, dan kegiatan;

3. Dana pensiun, badan penyelenggara jaminan sosial tenaga kerja, dan badan-badan lain yang membayar uang pensiun dan tunjangan hari tua atau jaminan hari tua;

4. Orang pribadi yang melakukan kegiatan usaha atau pekerjaan bebas;

5. Penyelenggara kegiatan, termasuk badan pemerintah, organisasi yang bersifat nasional, perkumpulan, orang pribadi serta lembaga lainnya yang menyelenggarakan kegiatan, yang membayar honorarium, hadiah, atau penghargaan dalam bentuk apa pun kepada wajib pajak orang pribadi dalam negeri berkenaan dengan suatu kegiatan.

\section{Penghasilan Kena Pajak (PKP)}

Penghasilan Kena Pajak (PKP) merupakan dasar perhitungan untuk menentukan besarnya Pajak Penghasilan yang terutang. Untuk menentukan besarnya Penghasilan Kena Pajak, yaitu dengan cara Penghasilan Neto dikurangi dengan Penghasilan Tidak Kena Pajak yang sebenarnya. Namun apabila penghasilan Netonya lebih kecil dari pada Penghasilan Tidak Kena Pajak maka Penghasilan Kena Pajaknya Nihil.

\section{Penghasilan Tidak Kena Pajak(PTKP)}

Berdasarkan Undang-Undang No.36 tahun 2008 tentang Pajak Penghasilan pada pasal 7 angka 1 menyatakan Penghasilan Tidak Kena Pajak yang berlaku adalah:

1. Rp.15.840.000,- untuk diri Wajib Pajak Pajak Orang Pribadi

2. Rp. 1.320.000,- tambahan untuk Wajib Pajak yang kawin.

3. Rp.15.840.000,- tambahan untuk seorang istri yang penghasilannya digabung dengan penghasilan suami, dengan syarat:

a. Penghasilan istri tidak semata-mata diterima atau diperoleh dari suatu pemberi kerja yang telah dipotong pajak berdasarkan ketentuan dalam Undang-Undang PPh Pasal 21, dan

b. Pekerjaaan istri tidak ada hubungannya dengan usaha atau pekerjaan bebas suami atau anggota keluarga lain.

4. Rp.1.320.000,- tambahan untuk setiap anggota keturunan sedarah semenda dalam garis keturunan lurus serta anak angkat yang ditanggung sepenuhnya, maksimal 3 orang untuk setiap keluarga. 
Peraturan Menteri Keuangan RI No. 162/PMK./011/2012 tentang penyesuaian besarnya Pengahasilan Tidak Kena Pajak yang ditetapkan pada tanggal 22 Oktober 2012.

Berikut adalah Jumlah Penghasilan Tidak Kena Pajak (PTKP) terbaru :

1. Untuk Diri Wajib Pajak Orang Peribadi = Rp. 24.300.000,-

2. Tambahan Untuk Wajib Pajak Kawin = Rp. 2.025.000,-

3. Tambahan untuk penghasilan istri yang digabung dengan penghasilan suami= Rp. 24.300.000,

4. Tambahan untuk anggota keluarga $(\max .3$ orang $)=$ Rp. 2.025.000,-

Dasarnya Penghasilan Tidak Kena Pajak (PTKP) diatur dalam pasal 7 UU Pajak Penghasilan, namum perubahan PTKP ini diperkenankan sesuai dengan Peraturan Menteri Keuangan, dan Peraturan ini berlaku detinitif mulai 1 Januari 2013.

Berikut ini akan disajikan tabel kenaikan Penghasilan Tidak Kena Pajak (PTKP) sesuai dengan status tanggungannya, yang mulai berlaku mulai tanggal 1 Januari 2013:

\section{Tabel 1. Kenaikan Penghasilan Tidak Kena Pajak (PTKP)}

\begin{tabular}{ccc}
\hline Keterangan & Tahun 2012 & Tahun 2013 \\
\hline Tidak Kawin (TK) & Rp 15.840.000 & Rp 24.300.000 \\
Tidak Kawin Tanggungan 1 (TK1) & Rp 17.160.000 & Rp 26.325.000 \\
Tidak Kawin Tanggungan 2 (TK2) & Rp 18.480.000 & Rp 28.350.000 \\
Tidak Kawin Tanggungan 3 (TK3) & Rp 19.800.000 & Rp 30.375.000 \\
Kawin (K) & Rp 17.160.000 & Rp 26.325.000 \\
Kawin Tanggungan 1 (K1) & Rp 18.480.000 & Rp 28.350.000 \\
Kawin Tanggungan 2 (K2) & Rp 19.800.000 & Rp 30.375.000 \\
Kawin Tanggungan 3 (K3) & Rp 21.120.000 & Rp 32.400.000 \\
\hline
\end{tabular}

Sumber: UU No. 36 tentang PPh dan PeMenKeu No.162/PMK./011/2012

\section{Tarif Pajak Penghasilan Pasal 21}

Tarif merupakan tolak ukur untuk menetapkan beban pajak, dalam hal ini PPh Pasal 21 menganut sistem tarif progresif dimana persentase tarif yang digunakan semakin besar bila jumlah yang dikenai pajak semakin besar

Tabel 2. Tarif Pajak Penghasilan yang diterapkan atas PTKP WP orang pribadi dalam negeri

\begin{tabular}{lc}
\hline \multicolumn{1}{c}{ Lapisan Penghasilan Kena Pajak } & Tarif Pajak \\
\hline Sampai dengan Rp. 50. 000.000,- & $5 \%$ \\
Di atas Rp. 50.000.000,- sampai dengan Rp. 250.000.000,- & $15 \%$ \\
Di atas Rp. 250.000.000,- sampai dengan Rp. 500.000.000,- & $25 \%$ \\
Di atas Rp. 500.000.000,- & $30 \%$ \\
\hline
\end{tabular}

Sumber: UU No. 36 tentang Pajak Penghasilan 


\section{Surat Pemberitahuan (SPT)}

Surat Pemberitahuaan (SPT) adalah surat yang oleh Wajib Pajak digunakan untuk melaporkan perhitungan dan/atau pembayaran pajak, objek pajak dan/atau bukan objek pajak, dan/atau harta dan kewajiban sesuai dengan ketentuan peraturan perundang-undangan perpajakan.

Fungsi Surat Pemberitahuan bagi Wajib Pajak Pajak Penghasilan adalah sebagai sarana untuk melaporkan dan mempertanggungjawabkan penghitungan jumlah pajak yang sebenarnya terutang dan untuk melaporkan tentang:

1. pembayaran atau pelunasan pajak yang telah dilaksanakan sendiri dan/atau melalui pemotongan atau pemungutan pajak pihak lain dalam 1 (satu) Tahun Pajak atau bagian Tahun Pajak;

2. penghasilan yang merupakan objek pajak dan/atau bukan objek pajak ;

3. harta dan kewajiban; dan/atau

4. pembayaran dari pemotongan atau pemungut tentang pemotongan atau pemungutan pajak orang pribadi atau badan lain dalam 1 (satu) Masa Pajak sesuai dengan ketentuan peraturan perundang-undangan perpajakan.

Fungsi Surat Pemberitahuaan bagi pemotong atau pemungut pajak, adalah sebagai sarana untuk melaporkan dan mempertanggungjawabkan pajak yang dipotong atau dipungut atau disetorkannya. Secara garis besar SPT dibedakan menjadi dua, yaitu:

1. Surat Pemberitahuan Masa adalah surat pemberitahuan untuk suatu Masa Pajak.

2. Surat Pemberitahuan Tahunan adalah surat Pemberitahuan untuk suatu Tahun Pajak atau Bagian Tahun Pajak.

Wajib Pajak dengan kemauan sendiri dapat membetulkan Surat Pemberitahuan yang telah disampaikan dengan menyampaikan pernyataan tertulis, dengan syarat Direktur Jendral Pajak belum melakukan tindakan pemeriksaaan. Hal pembetulan Surat Pemberitahuan menyatakan rugi atau lebih bayar, pembetulan Surat Pemberitahuan harus disampaikan paling lama 2 (dua) tahun sebelum daluwarsa penetapan. Dalam hal Wajib Pajak membetulkan sendiri Surat Pemberitahuan Tahunan yang mengakibatkan utang pajak menjadi besar, kepadanya dikenai sanksi administrasi berupa bunga sebesar $2 \%$ (dua persen) per bulan atas jumlah pajak yang kurang bayar, dihitung sejak jatuh tempo pembayaran sampai dengan tanggal pembayaran, dan bagian dari bulan dihitung penuh 1 (satu) bulan.

Batas waktu penyampaian Surat Pemberitahuan adalah:

1. untuk Surat Pemberitahuan Masa, paling lama 20(dua puluh) hari setelah akhir Masa Pajak;

2. untuk Surat Pemberitahuan Tahunan Pajak Penghasilan Wajib Pajak orang pribadi, paling lama 3 (tiga) bulan setalah akhir Tahun Pajak;

3. untuk Surat Pemberitahuan Tahunan Pajak Penghasilan badan, paling lama 4 (empat) bulan setalah akhir Tahun Pajak.

Surat Pemberitahuan yang tidak disampaikan dalam jangka waktu yang telah ditentukan atau batas waktu perpanjangan penyampaian Surat Pemberitahuaan, maka dikenai sanksi administrasi berupa denda sebesar, Rp. 100.000,00 (seratus ribu rupiah) untuk Surat Pemberitahuan Masa Pajak Penghasilan Wajib Pajak orang Pribadi.

\section{Surat Setoran Pajak (SSP)}

Surat Setoran Pajak (SSP) adalah bukti pembayaran atau penyetoran pajak yang telah dilakukan dengan menggunakan formulir atau telah dilakukan dengan cara lain ke kas Negara melalui tempat pembayaran yang ditunjuk oleh Menteri Keuangan. Surat Setoran Pajak (SSP) berfungsi sebagai bukti pembayaran pajak apabila telah disahkan oleh Pejabat kantor penerima pembayaran yang berwenang atau apabila telah mendapatkan validasi, tempat pembayaran dan penyetoran pajak dapat dilakukan di Bank yang ditunjuk oleh Menteri Keuangan dan/atau di Kantor Pos. Batas waktu pembayaran atau penyetoran $\mathrm{PPh}$ Pasal 21 yang dipotong oleh Pemotong PPh harus disetor paling lama tanggal 10 (sepuluh) bulan berikutnya setelah Masa Pajak berakhir. 


\section{Penelitian Terdahulu}

Tabel 3. Penelitian Terdahulu

\begin{tabular}{|c|c|c|c|c|c|c|}
\hline Peneliti & Judul & Tujuan & $\begin{array}{c}\text { Metode } \\
\text { penelitian }\end{array}$ & Hasil & Persamaan & Perbedaan \\
\hline $\begin{array}{l}\text { Rochman } \\
\text { (2006) }\end{array}$ & $\begin{array}{l}\text { Analisis } \\
\text { Pelaksanaan } \\
\text { Pemotongan, } \\
\text { Penyetoran, } \\
\text { dan Pelaporan } \\
\text { Pajak } \\
\text { Penghasilan } \\
\text { Pasal 21 Atas } \\
\text { Pegawai Tetap } \\
\text { Pada Dinas } \\
\text { Kesehatan } \\
\text { Kabupaten } \\
\text { Bangkalan. }\end{array}$ & $\begin{array}{l}\text { Untuk } \\
\text { mengetahui } \\
\text { Analisis yang } \\
\text { dilakukan } \\
\text { dengan } \\
\text { membandingkan } \\
\text { Pemotongan, } \\
\text { Penyetoran, dan } \\
\text { Pelaporan PPh } \\
\text { Pasal } 21 \text { yang } \\
\text { telah } \\
\text { dilaksanakan } \\
\text { oleh Dinkes } \\
\text { dengan } \\
\text { Penghitungan, } \\
\text { Penyetoran, dan } \\
\text { Pelaporan yang } \\
\text { sesuai dengan } \\
\text { Peraturan } \\
\text { Perpajakan yang } \\
\text { berlaku. }\end{array}$ & $\begin{array}{l}\text { Metode } \\
\text { yang } \\
\text { digunakan } \\
\text { yaitu } \\
\text { kualitatif } \\
\text { dengan } \\
\text { pendekatan } \\
\text { studi kasus. }\end{array}$ & $\begin{array}{l}\text { Dinkes } \\
\text { kurang tepat } \\
\text { dalam } \\
\text { menerapkan } \\
\text { pemotongan } \\
\text { n PPh Pasal } \\
\text { 21, dalam } \\
\text { artian tidak } \\
\text { sesuai } \\
\text { dengan } \\
\text { Peraturan } \\
\text { Perpajakan } \\
\text { yang berlaku } \\
\text { yaitu } \\
\text { Peraturan } \\
\text { Menteri } \\
\text { Keuangan } \\
\text { No.15/PJ/20 } \\
06 .\end{array}$ & $\begin{array}{l}\text { Kedua } \\
\text { penelitian ini } \\
\text { coba } \\
\text { membandingka } \\
\text { n, Penyetoran } \\
\text { dan Pelaporan } \\
\text { PPh Pasal } 21 \\
\text { yang dilakukan } \\
\text { perusahaan } \\
\text { apakah telah } \\
\text { sesuai dengan } \\
\text { Peraturan } \\
\text { Perpajakan } \\
\text { yang berlaku. }\end{array}$ & $\begin{array}{l}\text { Tidak } \\
\text { melakukan } \\
\text { analisa } \\
\text { terhadap } \\
\text { perhitungan } \\
\text { Pajak } \\
\text { Penghasilan } \\
\text { Pasal } 21 \\
\text { sedangkan } \\
\text { penelitian ini } \\
\text { melakukannya } \\
\text {. }\end{array}$ \\
\hline $\begin{array}{l}\text { Oktavan } \\
\text { (2010) }\end{array}$ & $\begin{array}{l}\text { Analisis } \\
\text { Perhitungan, } \\
\text { Penyetoran, } \\
\text { dan Pelaporan } \\
\text { Pajak } \\
\text { Penghasilan } \\
\text { Pasal } 21 \text { Pada } \\
\text { PT Assanacita } \\
\text { Mitrabangsa. }\end{array}$ & $\begin{array}{l}\text { Untuk } \\
\text { mengetahui } \\
\text { apakah } \\
\text { Perhitungan, } \\
\text { Penyetoran, dan } \\
\text { Pelaporan Pajak } \\
\text { Penghasilan } \\
\text { Pasal 21 pada PT } \\
\text { Assanacita } \\
\text { Mitrabangsa } \\
\text { sudah sesuai } \\
\text { dengan peraturan } \\
\text { Perundang- } \\
\text { Undangan } \\
\text { Perpajakan yang } \\
\text { berlaku di } \\
\text { Indonesia }\end{array}$ & $\begin{array}{l}\text { Menggunak } \\
\text { an metode } \\
\text { penelitian } \\
\text { deskriptif. }\end{array}$ & $\begin{array}{l}\text { Hasil dari } \\
\text { penelitian } \\
\text { ini, } \\
\text { menunjukan } \\
\text { bahwa } \\
\text { penerapan } \\
\text { Perhitungan } \\
\text { Penyetoran, } \\
\text { dan } \\
\text { Pelaporan } \\
\text { Pajak } \\
\text { Penghasilan } \\
\text { Pasal } 21 \\
\text { belum sesuai } \\
\text { dengan } \\
\text { peraturan } \\
\text { perundang- } \\
\text { undangan } \\
\text { perpajakan } \\
\text { yang berlaku } \\
\text { di Indonesia. }\end{array}$ & $\begin{array}{l}\text { Persamaannya } \\
\text { dalah kedua } \\
\text { penelitian ini } \\
\text { coba } \\
\text { membandingka } \\
\text { n apakah } \\
\text { Perhitungan, } \\
\text { Penyetoran, dan } \\
\text { Pelaporan PPh } \\
\text { Pasal } 21 \text { yang } \\
\text { dilakukan } \\
\text { perusahaan } \\
\text { telah sesuai } \\
\text { dengan } \\
\text { Peraturan } \\
\text { Perpajakan } \\
\text { yang berlaku. }\end{array}$ & $\begin{array}{l}\text { Perbedaan dari } \\
\text { kedua } \\
\text { penelitian ini } \\
\text { terletak pada } \\
\text { objek } \\
\text { penelitiannya. }\end{array}$ \\
\hline
\end{tabular}

Sumber : Data Olahan 2013 


\section{METODE PENELITIAN}

\section{Jenis Penelitian}

Jenis Penelitian yang digunakan dalam Penelitian ini adalah penelitian deskriptif, yaitu dengan mengumpulkan data yang berhubungan dengan permasalahan yang dihadapi. Data merupakan keteranganketerangan yang diperoleh dari penelitian dan atau melalui referensi untuk dapat digunakan dalam menganalisa Perhitungan, Penyetoran dan Pelaporan Pajak Penghasilan Pasal 21 Pada PT Intraco Penta Prima Servis (IPPS) apakah telah sesuai dengan Undang-Undang Perpajakan No.36 Tahun 2008 Tentang Pajak Penghasilan.

\section{Prosedur Penelitian}

Prosedur penelitian adalah langkah-langkah yang digunakan sebagai alat untuk mengumpulkan langkah dan menjawab pertanyaan-pertanyaan dalam penelitian. Langkah-langkah tersebut yaitu :

1. Mengumpulkan teori-teori yang berhubungan dengan Perhitungan, Penyetoran dan Pelaporan Pajak Penghasilan Pasal 21.

2. Memilih prosedur serta teknik yang digunakan

3. Mencari data yang akan digunakan

4. Memberikan kesimpulan dan saran sehingga dapat menjadi masukan bagi pihak PT Intraco Penta Prima Servis (IPPS).

\section{Objek Penelitian}

Objek penelitian adalah Perhitungan, Penyetoran dan Pelaporan Pajak Penghasilan Pasal 21 Pada PT Intraco Penta Prima Servis (IPPS).

\section{Metode Pengumpulan Data Jenis Data}

Data adalah sekumpulan informasi yang diperlukan untuk pengambilan keputusan. Kuncoro (2003) dalam melakukan penelitian jenis data yang digunakan adalah:

1. Data Kuantitatif adalah data yang diukur dalam suatu angka numeric, data kuantitatif dalam penelitian ini berupa daftar gaji karyawan PT Intraco Penta Prima Servis, (IPPS).

2. Data Kualitatif adalah data yang tidak dapat diukur dalam skala numeric, atau dalam bentuk uraian. Data kualitatif dalam penelitian ini berupa data mengenai kondisi perusahaan misalnya profil perusahaan. sejarah perusahaan, dan struktur organisasi.

\section{Sumber Data}

Sumber Data yang digunakan dalam penelitian ini adalah data yang diperoleh berdasarkan dari dua sumber data, yaitu :

1. Data Primer adalah sumber data penelitian yang diperoleh secara langsung dari sumber data asli (tidak melalui media perantara), Data primer dalam penelitian ini berupa data yang dikumpulkan, diolah dan diperoleh langsung dari PT Intraco Penta Prima Servis, (IPPS), yaitu berupa daftar gaji.

2. Data sekunder adalah data yang diperoleh secara tidak langsung melalui media perantara (diperoleh dan dicatat oleh pihak lain). Data sekunder dalam penelitian ini berupa buku-buku, artikel, ataupun jurnaljurnal yang berkaitan dengan perpajakan dan pajak penghasilan.

\section{Teknik Pengumpulan Data}

Teknik Pengumpulan Data dilakukan dengan cara sebagai berikut :

1. Penelitian lapangan, yaitu penelitian yang dilaksanakan dalam perusahaan secara langsung untuk memperoleh data sehubungan dengan masalah yang dibahas. Dalam penelitian ini penulis mengumpulkan data objek penelitian dengan cara sebagai berikut : 
a. Wawancara digunakan sebagai teknik pengumpulan data apabila peneliti ingin melakukan studi pendahuluan untuk menemukan permasalahan yang harus diteliti, dan juga apabila peneliti ingin mengetahui hal-hal dari responden yang lebih mendalam dan jumlah respondennya sedikit/kecil (Sugiyono, 2009: 194). Wawancara dilakukan dengan cara tanya jawab dengan pihak yang ditunjuk oleh PT Intraco Penta Prima Servis (IPPS) dalam hal ini bagian HR\&GA tentang cara Perhitungan, Penyertoran dan Pelaporan Pajak Penghasilan Pasal 21 yang dilakukan oleh perusaahaan.

b. Dokumentasi, yaitu pengumpulan data dengan menggunakan arsip atau dokumen-dokumen yang bersifat tulisan dari perusahaan berupa profil perusahaan, sejarah perusahaan, dan struktur organisasi.

2. Penelitian kepustakaan, yaitu penelitian yang dilakukan dengan cara mengumpulkan data dan keterangan dengan mempelajari teori-teori dan informasi yang berasal dari literatur-literatur lain yang berhubungan dengan masalah yang diteliti yaitu berupa buku-buku mengenai Perpajakan dan Pajak Penghasilan.

\section{Metode Analisis}

Metode Analisis yang digunakan adalah Metode Analisis Deskriptif, yaitu suatu metode analisa yang terlebih dahulu mengumpulkan data yang ada, kemudian diklasifikasikan, dianalisis, selanjutnya diinterpretasikan sehingga dapat memberikan gambaran yang jelas mengenai keadaan yang diteliti untuk menarik perhatian generalisasi yang bersifat umum.

\section{HASIL PENELITIAN DAN PEMBAHASAN}

\section{Sejarah Singkat Perusahaan}

PT Intraco Penta Prima Servis (IPPS), adalah salah satu dari tujuh anak perusahaaan PT Intraco Penta, Tbk yang bergerak di bidang penyedia berbagai jenis alat berat dengan merek tunggal Volvo dan SDLG, Volvo adalah adalah alat berat asal swedia, yang merupakan brand terkemuka yang telah teruji kekuatannya di pasar alat berat, jenis peralatan Volvo antara lain adalah Articulated Haulers, Excavator Hidrolik, Wheel Loaders, Motor Grades,dan Compactor, Sedangkan SDLG merupakan alat berat dari china, yang juga merupakan anak perusahaan Volvo CE. PT Intraco Penta Prima Servis, (IPPS), pada awalnya bernama PT Intraco Prima Servis yang berdiri pada tahun 2001, dan berganti nama setelah melalui keputusan perusahaan PT Intraco Penta, Tbk pada tahun 2011.

\section{Mekanisme Perhitungan Pajak Penghasilan Pasal 21}

Pajak Penghasilan Pasal 21 atas karyawan PT Intraco Penta Prima Servis, (IPPS), diperoleh dari Penghasilan Bruto yaitu gaji bulanan di tambah tunjangan jabatan dan tunjangan lain berupa lembur (jika ada) kemudian dikurangi dengan biaya asuransi sebesar 2\% dan biaya jabatan sebesar 5\% dari Penghasilan Bruto, dengan jumlah setinggi-tingginya Rp. 6.000.000,00 (enam juta rupiah) dalam setahun atau Rp. 500.000,00 (lima ratus ribu rupiah) dalam sebulan yang dihitung menurut banyaknya bulan perolehan dalam tahun yang bersangkutan, sebagaimana yang diaatur dalam Peraturan Menteri Keuangan No. 250/PMK.03/2008 tentang Besarnya Biaya Jabatan Atau Biaya Pensiun Yang Dapat Dikurangkan Dari Penghasilan Bruto Pegawai Tetap Atau Pensiunan, untuk memperoleh Penghasilan Neto. Penghasilan neto kemudian disetahunkan dan dikurangi dengan Penghasilan Tidak Kena Pajak (PTKP), maka diperoleh Penghasilan Kena Pajak (PKP), selanjutnya Penghasilan Kena Pajak (PKP) dikalikan dengan tarif Pasal 17 UU No. 36 Tahun 2008 untuk memperoleh utang Pajak Penghasilan Pasal 21 atas karyawan.

Berikut ini adalah contoh Perhitungan Pajak Penghasilan Pasal 21 untuk yang dilakukan oleh PT Intraco Penta Prima Servis (IPPS), sebagai berikut : 
1. Karyono selaku Branch Manager dengan besar Gaji Pokok Rp. 9.000.000,- /bulan dan menerima tunjangan jabatan sebesar Rp. 750.000,- dan membayar biaya Jamsostek dan biaya jabatan dengan status menikah anak 2 (K2), pada akhir tahun Karyono juga menerima Tunjangan Hari Raya (THR) sebesar Rp. 9.000.000,- (sama dengan gaji pokok).

Gaji sebulan

Tunjangan Jabatan

Pengurangan:

Biaya jabatan

5\% x Rp.9.750.000 ,-

Biaya Jamsostek

2\% x Rp. 9.750.000,-

Penghasilan Netto sebulan

Penghasilan Netto setahun

Tunjangan Hari Raya (THR)

PTKP setahun:

Untuk (K2)

PKP setahun

PPh Ps. 21 setahun

5\% x Rp. 50.000.000,-

$15 \%$ x Rp. 37.435.000,-

PPh Ps. 21 sebulan

Rp. 8.115.250: 12
=Rp. 9.000.000,-

$=$ Rp. $750.000,-$

=Rp. $9.750 .000,-$

$=$ Rp. $\quad 487.500,-$

$=$ Rp. $\quad 195.000,-$

$=$ Rp. $\quad 9.067 .500,-$

$=$ Rp.108.810.000,-

=Rp. 9.000.000,-+

$=$ Rp.117.810.000,-

Analisa 1:

Karyono selaku Branch Manager PT Intraco Penta Prima Servis (IPPPS), dengan status menikah dan memiliki dua orang anak (K2), Perhitungan Pajak Penghasilan Pasal 21 yang dipotong perusahaan telah sesuai dengan Ketentuan Pajak yang berlaku.

\section{Mekanisme Penyetoran dan Pelaporan PPh Pasal 21}

Prosedur Penyetoran dan Pelaporan Pajak Penghasilan Pasal 21 Pada PT Intraco Penta Prima Servis, (IPPS) adalah:

1. Pemotongan Pajak Penghasilan Pasal 21 dilakukan tiap bulan bersamaan dengan pembayaran gaji bulanan karyawan.

2. Pemotongan Pajak Penghasilan Pasal 21 dilakukan oleh bagian keuangan PT Intraco Penta Prima Servis, (IPPS) sebagai pemberi gaji.

3. PT Intraco Penta Prima Servis, (IPPS) menggunakan SPT Masa untuk melaporkan Pajaknya.

4. Penyetoran Pajak Penghasilan Pasal 21 yang telah dipotong dilaksanakan setiap bulan paling lambat tanggal 10 bulan gaji berikutnya ke Kantor Pelayanan Pajak (KPP) dengan disertai Surat Setoran Pajak (SSP). 
5. Pelaporan Pajak Penghasilan Pasal 21 dilaksanakan paling lambat 20 hari setelah akhir masa pajak tersebut. Pelaporan Pajak Penghasilan Pasal 21 tersebut dilaksanakan dengasn cara mengisi formulir SPT yang telah disediakan Kantor Pelayanan Pajak (KPP) disertai dengan rincian Penghasilan Kena Pajak (PKP) tiap karyawan, sebagaimana telah diatur dalam Peraturan Dirjen Pajak No. PER31/PJ/2012 tentang Pedoman Teknis Tata Cara Pemotongan, Penyetoran, Dan Pelaporan Pajak Penghasilan Pasal 21 dan/atau Pasal 26 Sehubungan Dengan Pekerjaan, Jasa, Dan Kegiatan Orang Pribadi.

\section{Pembahasan}

Berikut ini akan ditampilkan tabel perbandingan hasil perhitungan Pajak Penghasilan Pasal 21 atas gaji Karyawan menurut PT Intraco Penta Prima Servis, (IPPS) dan UU No. 36 Tahun 2008 hasil olahan penulis:

Tabel 4. Perbandingan Hasil Perhitungan PPh Pasal 21 menurut PT. IPPS dan UU No.36 Thn 2008

\begin{tabular}{cccc}
\hline Nama Karyawan & \multicolumn{3}{c}{ Pajak Penghasilan Pasal 21 ( Rupiah) } \\
\cline { 2 - 4 } & PT. IPPS. & UU No. 36 & Selisih \\
\hline Karyono (K2) & Rp.676.775,- & Rp. 676.775,- & Tidak ada \\
Josheph. K (K1) & Rp. 61.775,- & Rp. 61.775,-- & Tidak ada \\
Endrizal (TK) & Rp. 78.650,- & Rp. 78.650,- & Tidak ada \\
Dali Ichwan(TK) & Rp. 78.650,- & Rp. 78.650,- & Tidak ada \\
Khaidir (K1) & Rp. 46.342,- & Rp. 46.342,- & Tidak ada \\
Enggelina (TK) & Rp. 46.575,- & Rp. 46.575,-- & Tidak ada \\
Feydy Supit (TK) & Rp. 36.208,- & Rp. 36.208,- & Tidak ada \\
Ria (TK) & NIHIL & NIHIL & - \\
\hline
\end{tabular}

Sumber: Data olahan PT Intraco Penta Prima Servis, (IPPS), 2013.

Tabel tersebut diperoleh kesimpulan bahwa Perhitungan Pajak Penghasilan Pasal 21 atas gaji karyawan PT Intraco Penta Prima Servis, (IPPS), telah sesuai dengan UU No. 36 Tahun 2008 karena tidak didapati adanya selisih.

Surat Pemberitahuaan (SPT) adalah surat yang oleh Wajib Pajak digunakan untuk melaporkan perhitungan dan/atau pembayaran pajak, objek pajak dan/atau bukan objek pajak, dan/atau harta dan kewajiban sesuai dengan ketentuan peraturan perundang-undangan perpajakan. Sedangkan Kewajiban pelaporan dilakukan oleh wajib pajak dengan mengambil sendiri dan mengisi Surat Pemberitahuan serta menyampaikan kepada Kantor Pelayanan Pajak setempat atau Kantor Pelayanan Pajak yang ditetapkan bagi wajib pajak tertentu. Kantor Pelayanan Pajak tempat melapor adalah kantor dimana Wajib Pajak yang bersangkutan terdaftar, Dalam hal ini Perhitungan, Penyetoran dan Pelaporan Pajak Penghasilan Pasal 21 yang dilakukan oleh PT Intrco Penta Prima Servis (IPPS) mengacu kepada formulir SPT Masa Pajak Penghasilan.

Berikut ini akan disajikan tabel ketaatan penyetoran dan pelaporan SPT Masa Pajak Penghasilan Pasal 21 Pada PT Intraco Penta Prima Servis, (IPPS): 
Tabel 5. Ketaatan Penyetoran dan Pelaporan SPT Masa PPh Pasal 21 Pada PT. IPPS

\begin{tabular}{|c|c|c|c|}
\hline \multirow[t]{2}{*}{ Bulan/Masa Pajak } & \multicolumn{2}{|c|}{ Penyetoran } & \multirow[t]{2}{*}{ Keterangan } \\
\hline & PT IPPS & Paling lambat & \\
\hline Januari 2013 & 7 February 2013 & 10 February 2013 & \multirow{12}{*}{$\begin{array}{c}\text { Telah sesuai dengan } \\
\text { UU No. } 36 \text { Tahun } \\
2008\end{array}$} \\
\hline February 2013 & 7 Maret 2013 & 10 Maret 2013 & \\
\hline Maret 2013 & 4 Apil 2013 & 10 April 2013 & \\
\hline April 2013 & 9 Mei 2013 & 10 Mei 2013 & \\
\hline Mei 2013 & 6 Juni 2013 & 10 Juni 2013 & \\
\hline Juni 2013 & 4 July 2013 & 10 July 2013 & \\
\hline July 2013 & 8 Agustus 2013 & 10 Agustus 2013 & \\
\hline Agustus 2013 & 5 September 2013 & 10 September 2013 & \\
\hline September 2013 & 10 Oktober 2013 & 10 Oktober 2013 & \\
\hline Oktober 2013 & 7 November 2013 & 10 November 2013 & \\
\hline November 2013 & 5 Desember 2012 & 10 Desember 2013 & \\
\hline \multirow[t]{3}{*}{ Desember 2013} & Belum disetor & 10 Januari 2014 & \\
\hline & \multicolumn{2}{|c|}{ Pelaporan } & \\
\hline & PT IPPS & Paling Lambat & \\
\hline Januari 2013 & 14 February 2013 & 20 February 2013 & \multirow{12}{*}{$\begin{array}{c}\text { Telah sesuai dengan } \\
\text { UU No. } 36 \text { Tahun } \\
2008\end{array}$} \\
\hline February 2013 & 14 Maret 2013 & 20 Maret 2013 & \\
\hline Maret 2013 & 11 April 2013 & 20 April 2013 & \\
\hline April 2013 & 16 Mei 2013 & 20 Mei 2013 & \\
\hline Mei 2013 & 13 Juni 2013 & 20 Juni 2013 & \\
\hline Juni 2013 & 11 July 2013 & 20 July 2013 & \\
\hline July 2013 & 15 Agustus 2013 & 20 Agustus 2013 & \\
\hline Agustus 2013 & 12 September 2013 & 20 September 2013 & \\
\hline September 2013 & 17 Oktober 2013 & 20 Oktober 2013 & \\
\hline Oktober 2013 & 17 November 2013 & 20 November 2013 & \\
\hline November 2013 & 12 Desember 2013 & 20 Desember 2013 & \\
\hline Desember 2013 & Belum dilapor & 20 Januari 2014 & \\
\hline
\end{tabular}

Sumber: PT Intraco Penta Prima Servis (IPPS), 2013.

Penyetoran dan Pelaporan SPT Masa PT Intraco Penta Prima Servis (IPPS), telah dilakukan sesuai dengan Peraturan Perpajakan yang berlaku, yakni penyetorannya dilakukan paling lambat Tanggal 10 bulan berikutnya dan Pelaporan dilakukan Paling lambat 20 hari setelah akhir masa Pajak, dan apabila tanggal Penyetoran dan Pelaporan tersebut jatuh pada hari libur atau hari minggu, maka tanggal Penyetoran dan Pelaporannya dapat digeser pada hari kerja.

\section{PENUTUP}

\section{Kesimpulan}

Berdasarkan hasil penelitian yang telah dilakukan penulis pada PT Intraco Penta Prima Servis (IPPS), dapat disimpulkan sebagai berikut:

1. PT Intraco Penta Prima Servis (IPPS), dalam Perhitungan, Penyetoran dan Pelaporan Pajak Penghasilan Pasal 21 telah sesuai dengan ketentuan Peraturan Perpajakan yang berlaku yaitu Undang-Undang No.36 Tahun 2008 Tentang Pajak Penghasilan.

2. Penyetoran dan Pelaporan Pajak yang dilakukan PT. Intraco Penta Prima Servis (IPPS), pada kantor pelayanan pajak telah dilakukan dengan tepat waktu. 


\section{Saran}

sebagai berikut:

Setelah melakukan Penelitian ini dan Berdasarkan hasil analisis maka penulis dapat memberi saran

1. PT Intraco Penta Prima Servis (IPPS), harus sering mengupdate informasi pajak terbaru, agar sesuai dengan Peraturan Perpajakan yang berlaku, serta meningkatkan kualitas petugas yang berwenang (bendahara) mengenai pengetahuan Perpajakan.

2. Pihak fiskus harus lebih banyak memberikan sosialisasi mengenai Pajak Penghasilan Pasal 21 kepada Wajib Pajak khususnya yang bertindak sebagai pemotong atau pemungut pajak sehingga tidak terjadi lagi kesalahan-kesalahan dalam perhitungan.

\section{DAFTAR PUSTAKA}

Kuncoro, Mudrajat. 2003. Metode Riset Untuk Bisnis Dan Ekonomi, Erlangga. Jakarta.

Mardiasmo. 2009. Perpajakan. Edisi Revisi. Andi. Yogyakarta.

Oktavan 2010. Analisis Perhitungan, Penyetoran, dan Pelaporan Pajak Penghasilan Pasal 21 Pada PT Assanacita Mitrabangsa. Skripsi Universitas Mercubuana. Jakarta. http://digilib.mercubuana.ac.id/skripsi1.php?ID_Skripsi=0000017593/.Diakses Mei, 24, 2013

Republik Indonesia. Undang-Undang No.36 Tahun 2008, mengenai perubahan ketiga atas UndangUndang No.16 Tahun 2000 tentang Ketentuan Umum dan Tata cara Perpajakan. Jakarta. http://www.pajak.go.id/dmdocuments/UU-36-2008.pdf/. Diakses April, 05, 2013

. Undang-Undang No. 36 Tahun 2008 mengenai perubahan keempat atas UndangUndang No. 17 Tahun 2000 tentang Pajak Penghasilan, Jakarta. http:// www.bpkp.go.id/uu I. Diakses April, 05, 2013

. Peraturan Menteri Keuangan No. 162/PMK.011/2012. tentang Penyesuaian besarnya Penghasilan Tidak Kena Pajak. Jakarta.

http://www.ortax.org/ortax/?mod=aturan\&page=show\&id=15122/. Diakses Juli, 06, 2013.

. Peraturan Menteri Keuangan No. 250/PMK.03/2008 tentang Besarnya Biaya Jabatan Atau Biaya Pensiun Yang Dapat Dikurangkan Dari Penghasilan Bruto Pegawai Tetap Atau Pensiunan. Jakarta http://www.ortax.org/ortax/?mod=aturan\&page=show\&id=13573/. Diakses Sep, 09, 2013. . Peraturan Dirjen Pajak No. PER-31/PJ/2012 tentang Pedoman Teknis Tata Cara Pemotongan, Penyetoran, Dan Pelaporan Pajak Penghasilan Pasal 21 dan/atau Pasal 26 Sehubungan Dengan Pekerjaan, Jasa, Dan Kegiatan Orang Pribadi. Jakarta. http://www.slideshare.net/gusmanshor/p-ph-pasal-21/. Diakses Juni, 13, 2013.

Rochman 2006. Analisis Pelaksanaan Pemotongan, Penyetoran, dan Pelaporan Pajak Penghasilan Pasal 21 Atas Pegawai Tetap Pada Dinas Kesehatan Kabupaten Bangkalan. Skripsi. Universitas Airlangga. Surabaya.

http:/skripsiakuntan.blogspot.com/2013/05/penghitungan-PPh-pasal-21 /.Diakses Mei,24, 2013 Sugiyono. 2009. Metode Penelitian Bisnis. CV. Alfabeta. Bandung. 